\title{
Violència divina? \\ Sobre violència, política i religió a partir de Žižek i Derrida
}

\author{
Laura Llevadot \\ Universitat de Barcelona \\ laullevadot@ub.edu
}

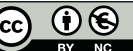

Data de recepció: $19-7-2013$

Data d'acceptació: $23-9-2013$

\section{Resum}

L'objectiu d'aquest article és qüestionar el lligam que, sovint, s'estableix entre violència i religió, per tal d'oposar-les a la racionalitat política com a condició de la democràcia. Amb l'objectiu de mostrar les dificultats que sotgen aquest tipus d'arguments, analitzaré alguns aspectes del pensament eticopolític de Žižek i Derrida, així com la referència dels dos pensadors al cèlebre text de Walter Benjamin sobre la violència. D’aquesta manera, es tractarà d'evidenciar que un pensament que esborra les fronteres metafísiques clàssiques entre política i religió no ha de caure pas en posicions conservadores, sinó que, ben al contrari, és capaç d'articular un concepte de democràcia molt més exigent i rigorós.

Paraules clau: violència; violència divina; política; religió; Žižek; Derrida; Benjamin.

\section{Abstract. Divine violence?: On violence, politics and religion from Žižek and Derrida}

The main objective of this paper is to criticize the usual link between violence and religion in order to oppose them to political rationality and democracy. In order to show the problems that arise from this argument, I will analyze some aspects of the Žižek and Derrida's ethico-political thought, as well as their reference to Walter Benjamin's famous text on violence. In this way, I will show how a thought that erases the classical metaphysical borders between the political and the religious is not conservative, but on the contrary it can articulate a radical and rigorous concept of democracy.

Keywords: violence; divine violence; politics; religion; Žižek; Derrida; Benjamin.

\section{Sumari}

1. Un filosofema clàssic: 3 . La crítica al gir teologicopolític violència i racionalitat Referències bibliogràfiques

2. La crítica de la violència

* Aquest treball ha estat realitzat en el marc del projecte de recerca FFI2012-30644, finançat pel Ministeri d'Economia i Competitivitat. 


\section{Un filosofema clàssic: violència i racionalitat}

L'escena es repeteix massa sovint. El juliol de 2011, un empresari noruec va disparar contra els membres d'un campament juvenil del partit laborista i va acabar amb la vida d'una setantena de persones, amb l'única justificació, segons ell mateix va declarar, que tenia motius religiosos i antimulticulturalistes que així li ho exigien. Deu anys abans, havien tingut lloc els atemptats a les Torres Bessones, i suposadament també per causes vinculades al fet religiós, tot i que aquesta vegada no havia estat el fonamentalisme cristià, sinó l'islàmic, el que havia servit d'esperó. Al llarg dels dies que segueixen aquests tipus d'atrocitats, als diaris, sempre hi podem llegir articles d'opinió que condemnen l'obscurantisme religiós o el perill dels fonamentalismes i que apel.len a la necessitat de dur a terme un ordenament laic i racional del món i de les ànimes. El professor Stephen Bronner, per exemple, en la seva Carta oberta a Benet XVI, clamava a favor de la racionalitat en els termes següents: «Fe, mite i dogma són al cor de la servitud i de l'autoritarisme. Crítica, ciència i tolerància encarnen la petita esperança que resta als que ja no tenen esperança» (Bronner, 2005) ${ }^{1}$. No és que els manqui raó als qui argumenten així, de fet, els en sobra. Potser caldria començar a qüestionar-se la pertinença de l'oposició. No només d'aquella que separa fe, mite i dogma, d'una banda, de crítica, ciència i tolerància, de l'altra, com si la fe en la ciència no hagués generat més d'una atrocitat —i no serà necessari multiplicar-ne aquí els exemples—, sinó que es tractaria de qüestionar l'oposició mateixa, la lògica de l'oposició que tendeix a separar allò que, de fet, es mostra indiscernible. És aquesta mateixa lògica la que Hannah Arendt tractava de fer valer en els seus textos sobre la violència quan, amb un racisme palmari, que només per obscures raons pot haver passat inadvertit, oposava la "violència negra», la d'aquells "Negro students», que «havien estat admesos sense la necessària aptitud acadèmica» i l'únic interès dels quals era «reduir els nivells acadèmics» (Arendt, 1970: 24) —són les seves pròpies paraules, malgrat que ens dolgui-, a la veritable acció política, aquella que es distingeix del mer comportament per ser capaç de generar canvis estructurals a llarg termini. Caldria recórrer aquests textos d'Arendt sobre la violència amb un escarpell per tal d'advertir els ingents intents en desequilibri perpetu, per distingir l'acció de la violència, el blanc del negre, el que és racional del que és irracional i injustificable.

La crítica a la violència ha estat sempre un problema complex, especialment en la filosofia política moderna. D’una banda, el pensament il.lustrat voldria erigir-se en baluard de la racionalitat davant de l'obscurantisme religiós, així com davant l'autoritarisme teologicopolític, però, alhora, la violència revolucionària, si més no des de Sorel, sembla que exigeix un element irracional, si no diví, que imprimeixi a l'acció la força de convicció i la creença en la possibilitat de canviar. El que sembla nou, tanmateix, és que el problema de la violència revolucionària s'hagi fos avui amb un suposat "retorn del fet religiós», 
com si, després del fracàs del projecte il-lustrat que s'encaminava a assegurar la pervivència d'una societat laica i racional, s'haguessin despertat les obscures forces de tot el que és mitològic reclamant a la desesperada el seu lloc al món, com si el fet religiós menyspreat iniciés ara la seva revenja en plena postmodernitat. Tanmateix, caldria afinar l'anàlisi per tal de poder comprendre què és el que hi ha en joc en aquest tipus d'esdeveniments que ens desperten del nostre encanteri. Si ens commouen, si ens arrabassen la pau, no hauria de ser amb la finalitat d'afirmar-nos en les nostres conviccions de ciutadans amb bona consciència, sinó més aviat per mostrar-nos les idealitats que ens travessen, que conformen la nostra mirada, i que hauríem de poder pensar amb una mica més de deteniment. Potser Žižek i Derrida podran ser-nos d'utilitat en aquesta tasca. Malgrat les innumerables diferències que separen els dos pensadors, tant estilísticament com pel que fa als seus plantejaments teòrics, tots dos han coincidit a pensar «la mateixa font», aquella que problematitza, en primer lloc, l'oposició de la violència a la no-violència, tant com aquella altra que contraposa massa fermament la religiositat al fet polític.

\section{La crítica de la violència}

Hauríem de sospitar sempre de la crítica a la violència sense més ni més, d'aquella crítica que, d'entrada, pretén situar-se en la no-violència per tal de condemnar la violència com quelcom exterior. Žižek i Derrida comparteixen sens dubte la crítica a aquest tipus de crítica, el rebuig a la «crítica liberal» de la violència, a la seva voluntat d'estigmatitzar-la alhora que, en el mateix gest, $s$ 'invisibilitza la violència constitutiva del marc social en què aquesta violència té lloc. Marx ja denunciava que la violència capitalista tendeix a ocultar-se com a violència i a naturalitzar-se fins a fer-se irreconeixible, i Žižek recull quelcom d'això quan apunta que: «anatematitzar la violència, condemnar-la com a dolenta és una operació ideològica per excel-lència, una mistificació que col-labora en la invisibilització de les formes fonamentals de la violència social. És profundament simptomàtic que les societats occidentals, tan sensibles a les diferents formes de persecució, siguin també capaces de posar en marxa infinitat de mecanismes destinats a fer-nos insensibles a les formes més brutals de la violència» (Žižek, 2009: 174).

D’altra banda, Derrida, quan, a Donner la mort, emprèn l'anàlisi de l'acció d'Abraham en la seva versió kierkegaardiana, recorda que, darrere de totes les condemnes airades i benintencionades del sacrifici d'Abraham, també hi ha, en realitat, un gest d'invisibilització de tots aquells actes expiatoris que fem cada dia quan, en preferir donar de menjar, estimar, cuidar o salvar algú, ni que sigui un gat, sacrifiquem, de manera conscient o inconscient, tots els altres que deixem morir, sovint de fam: «Insistim aquí, en nom de la moralitat de la moralitat, sobre allò que, massa sovint, obliden els moralistes moralitzants i les bones consciències que no deixen de recordar-nos amb fermetat, tots els dies $\mathrm{o}$ totes les setmanes, als diaris, als setmanaris, a les emissores de ràdio i a la televisió, el sentit de les responsabilitats ètiques i polítiques. [...] Allò que els 
cavallers de la bona consciència desconeixen és que el sacrifici d'Isaac il.lustra, si podem emprar aquest terme, en el cas d'un misteri tan nocturn, l'experiència més quotidiana i comuna de la responsabilitat» (Derrida, 1992: 53). Aquesta experiència quotidiana mostra bé que, en el nucli del concepte de responsabilitat, hi habita la irresponsabilitat més absoluta, que allà on ens sentim bons i responsables perquè hem actuat com calia, encara més si hem seguit l'imperatiu kantià, hauríem de recordar a tots aquells a qui en el mateix acte hem deixat de costat, ens hem irresponsabilitzat per amor de l'objecte triat en la nostra acció responsable. En triar allò que faig en aquest moment, «sacrifico, traint-les a cada instant, totes les meves altres obligacions: en allò que es refereix als altres "altres" que no conec o que conec, milers dels meus consemblants que moren cada dia de fam o de malaltia» (Derrida, 1992: 71). Alço el ganivet, com Abraham davant d'Isaac, cada cop que crec que sóc responsable, just perquè, en el concepte mateix de responsabilitat, hi nia la violència envers l'altre de l'altre, de qui, tanmateix, em sento dispensat. Hi ha, doncs, tant per a Žižek com per a Derrida, una certa hipocresia en tota condemna de la violència, un no voler mirar cap a la pròpia condició de possibilitat que ens fa creure que som bons, pacífics i tolerants, quan, en realitat, estem exercint la pitjor de les violències, aquella que s'oculta a si mateixa.

Aleshores, com que la condemna de la violència sempre és violenta, semblaria que s'obren les portes a la legitimació d'una violència capaç de desestabilitzar la violència estructural que el discurs pacífic, liberal i benintencionat provaria de dissimular. Tota una tradició política marxista va poder articularse al voltant d'aquesta possibilitat que Engels, a l'Anti-Dühring, contraposava a la «mentalitat de predicador»: «El senyor Dühring no sap una paraula sobre el fet que la violència acompleix també un altre paper a la història, un paper revolucionari; sobre el fet que, segons la paraula de Marx, és la llevadora de tota vella societat gràvida d'una altra de nova; sobre el fet que és l'instrument amb el qual el moviment social s'imposa i trenca formes polítiques enrigidides i mortes» (Engels, 2003: 177). Però avui no sembla pas tan facil contraposar la violència transformadora $i$ revolucionària a la violència sistèmica i estructural, i per les mateixes raons, per paradoxal que pugui semblar, per les que no seria ja possible oposar la política, o el poder en termes d'Arendt, a la violència. La pretensió de Hannah Arendt de salvaguardar la política o el poder democràtic de la violència, la sola possibilitat d'afirmar que «el poder i la violència són oposats; on l'un domina l'altra hi manca" (Arendt, 1970: 42), esdevé avui impensable, no només per la ingenuïtat que mostra, perquè obvia totes les violències que les institucions polítiques, tant com les d'aparença menys política (l'educació, la sanitat, les presons, i tantes altres que Foucault va saber analitzar), s'institueixen en virtut de violències discursives i tàctiques — d'aquí que Žižek hagi considerat l'elevació d'Arendt de les últimes dècades com el signe inequívoc de la derrota teòrica de les esquerres (Žižek, 2002: 3)—, sinó també per eludir l'oposició entre el que és polític i la política, la diferència elemental entre la força desestabilitzadora i constituent d'allò que és polític i la política com a àmbit de les limitacions instituïdes i de la representació. Sobre 
aquesta distinció, s'han articulat de fet totes les crítiques dels darrers anys a la democràcia representativa que, de Balibar a Abensour, passant per Rancière, miren de pensar la democràcia en termes d'insurrecció permanent (Abensour, 1997; Abensour, 2012: 31-48; Balibar, 1994: 205) i la política instituïda en termes de policia (Rancière, 1998). Que la limitació política de la violència sobre la que descansa l'estat de dret no la circumscriu des de fora sense, alhora, exercir-la, ho saben tant els darrers pensadors postmarxistes francesos, com tots els indignats que es mobilitzen avui a les nostres places per tal d'impugnar la maquinària de la representació democràtica en nom d'alguna cosa, així com una «democràcia real, ja». Tanmateix, és aquesta violència instituent i emancipatòria la que no sembla avui pensable sense rellegir, si més no un text paradigmàtic i fosc que intentava establir, ja l'any 1921, certa tipologia de la violència. Tant Žižek com Derrida, i caldrà afegir-hi Butler, hauran acceptat aquesta marrada per tal de pensar la insòlita "violència divina» que Benjamin hi esbossà.

A Cap a una crítica de la violència, Benjamin hi estableix una primera distinció entre la «violència conservadora» $\mathrm{i}$ «la violència fundadora» (Benjamin, 2007). La primera seria aquella violència que exerceix el dret, i totes les forces i les institucions que el secunden, en tractar de preservar un estat constituït determinat. La segona seria aquella violència constituent en virtut de la qual aquest estat es va arribar a establir. Semblaria, aleshores, que aquí es reprodueix la vella dicotomia entre potència i poder, el que és polític i la política, la violència constituent $\mathrm{i}$ la violència constituïda. Si bé és cert que aquesta sola distinció impugna ja la separació liberal entre política i violència, en fer dependre tot estat constituït d'una violència originària i fundadora, màcula de la qual cap política podria desfer-se per reivindicar la seva puresa. El cert és que Benjamin anomena aquesta violència fundadora «violència mítica», $i$ això per tal de diferenciar-la encara d'una altra violència. La violència mítica és, segons Benjamin, violència immediata, aquella que, sense ser un mitjà per a un fi, mera expressió de la ira continguda, esdevé instauradora de dret en culpabilitzar l'existència — seguint aquí el mite de Níobe- i justificar-ne, d'aquesta manera, la regulació ${ }^{2}$. El dret queda, així, marcat per sempre per aquesta violència originària $i$, alhora, necessita la violència per mantenir-se, «no renuncia ja a la violència", el dret limita l'ús de mitjans violents a través d'una violència conservadora, així com per mitjans aitals com la policia, que transgredeixen sovint les pròpies limitacions que l'ordenament jurídic estableix. És per això que "hi ha quelcom putrefacte en el dret» (Benjamin, 2007: 192), i per això mateix dirà Derrida que un dret tancat seria la pitjor de les violències. Hi ha quelcom de podrit en tot allò tancat, tant en el dret com en la política, i encara més en la policia, que els excedeix tots dos, car, en no reconèixer la violència performativa de la qual provenen, tendeixen a autoimmunitzar-se davant d'ella, per fer ús aquí de la terminologia de Derrida, a

2. Per a una explicació d'aquest doble moviment que dota la violència divina de finalitat, vegeu Esposito (2002). 
defensar-se violentament contra l'origen forçosament violent de la seva fundació $^{3}$. El terrorisme d'estat no té altre origen. Sorgeix allà on l'ordenament jurídic vigent se sent amenaçat per una altra força, potser també fundadora, i encobreix el seu origen violent justificant l'atac sense atenuants envers aquell «mal absolut» que amenaça amb el fet de posar en qüestió la seva pretesa integritat. De la mateixa manera que Robespierre justificava la decapitació sense judici del dèspota perquè el considerava fora de la llei ${ }^{4}$, l'estat de dret es concedeix la legitimitat d'exercir violència contra allò que el qüestiona. És aleshores quan tot s'hi val, perquè es considera l'amenaça com si fos fora de la llei $i$, per tant, es pot actuar també fora de la llei per protegir-se . Però l'autoimmunitat és justament un comportament suïcida, aquell que fa que un ésser viu destrueixi les seves pròpies defenses abans de ser atacat per adhesió a la seva pròpia integritat, per excés d'higiene. És així com les democràcies deixen de ser-ho per temor a ser destruïdes. En autoimmunitzar-se, com ara, per exemple: quan s'inicia una política contra «l'eix del mal», envers els «estats canalles» o el terrorisme, la democràcia comença a autodestruir-se i perd tota legitimitat: «la democràcia es protegeix i es manté limitant-se i amenaçant-se a si mateixa» (Derrida, 2003: 61). Sempre en el llindar de la seva autodestrucció, l'ordenament jurídic persisteix vigent en virtut d'una violència conservadora que nega la violència fundadora que el va fer néixer i que, alhora, l'amenaça des de fora, i contra la qual aquest ordenament no troba cap més manera de defensar-se que posant-se a si mateix en qüestió.

Però si Benjamin du a terme l'anàlisi de la violència mítica i de la seva conservació en el dret és justament per oposar-hi un altre tipus de violència, una violència legítima que anomenarà, seguint la tradició jueva en oposició a la grega, "violència divina»: «Si la violència mítica instaura dret, la violència divina l'aniquila; si aquella posa límits, aquesta destrueix il-limitadament; si la violència mítica inculpa i expia alhora, la divina redimeix» (Benjamin, 2007: 202). Aquesta violència redemptora $i$ incruenta serà l'ideal de violència que Benjamin oposa tant a la violència fundadora com a la conservadora. És la violència que ell veurà encarnada, per exemple, en la "vaga general proletària», que es distingeix de la "vaga general política», seguint Sorel, perquè és un mer mitjà per a un fi i fundadora de dret, mentre que la primera és anarquista i no busca modificacions exteriors de les condicions de treball. És justament aquest tipus de violència la que Žižek invoca en el seu assaig: «Violència divina significa aquí intrusió de la justícia més enllà de la llei» (Žižek, 2009: 251), i els exemples als quals fa esment són, sens dubte, espaordidors: la venjança de Grace a Dogville, el magnífic film de Lars von Trier, o la turba provinent de

3. Per una anàlisi del concepte de violència en el pensament de J. Derrida, remetem a Biset (2013).

4. José Luis Pardo (1998) fa referència al discurs de Robespierre en un article important per pensar aquesta relació entre la llei de la ciutat i el despotisme, o entre política i violència, en els termes que es plantegen aquí, tot i que la finalitat del text sigui ben diversa.

5. En aquest sentit «l'estat guerra» no seria tant un fenomen postmodern com el caràcter constitutiu de tot estat. Sobre aquesta noció, vegeu López Petit (2003). 
les faveles a Rio de Janeiro que va saquejar la zona rica de la ciutat. «Eren com llagostes bíbliques», comenta Žižek (2009: 171). Àdhuc si, com Badiou pretén, aquest tipus de violència pertanyés a l'ordre de l'esdeveniment i no de l'ésser (Zižek, 2009: 169), el cert és que la violència legítima a la qual aquí s'apunta té en tot cas un estatut inestable. Judith Butler ha intentat matisar aquest concepte en reparar en la qüestió de la «nua vida» a la qual fa referència Benjamin en el seu text i sobre la qual Agamben ha construït la seva crítica a l'estat de dret, perquè està fundat sobre l'estat d'excepció (Agamben, 2006). En el text, Benjamin escomet contra aquells qui condemnen la violència per tal de salvaguardar allò que hi ha de sagrat en tota vida: «la frase que diu que l'existència es troba per sobre de l'existència justa és falsa i abjecta" (Benjamin, 2007: 204) . La mera vida (blosses Leben) no pot ser mai l'aixopluc contra la crítica, cal que la vida estigui sempre connotada per allò que l'excedeix i la fa digna de ser viscuda, perquè aleshores l'única cosa sagrada seria la justícia i no pas la vida com a tal. Butler s'acull a aquesta concepció de la nua vida per intentar articular un concepte de violència divina que, lluny d'arremetre contra la vida, envesteix el subjecte jurídic que impedeix la justícia, i reprèn, a més, el model de la vaga per tractar d'articular aquesta violència divina en termes de rebuig a l'acció (Butler, 2006: 219). Però, malgrat tots els intents de pensar aquesta violència sota paràmetres revolucionaris i no autoritaris, el cert és que, en el si mateix d'aquesta distinció benjaminiana, hi sotja una dificultat. Derri$\mathrm{da}$, que estarà sens dubte d'acord amb la relació entre força i dret, violència $\mathrm{i}$ política, així com en l'aspiració a la justícia que travessa el text de Benjamin, planteja, tanmateix, la qüestió de si és realment possible oposar el que és jueu al que és grec, el que és diví al que és mític, la violència legítima a la il.legítima, tal com Benjamin voldria, i, en el fons més íntim de la seva lectura, hi sotja la temorosa interrogació: "Terroritza la idea d'una interpretació que faria de l'holocaust una expiació i una signatura indesxifrable de la justa i violenta còlera de Déu» (Derrida, 1994: 145), com terroritza la idea d'una justificació de la matança d'Utøya o dels atemptats de les Torres Bessones en termes de "violència divina», que és justament com es presenten a si mateixos. I és que sembla ben cert que, com afirma també Badiou, no hi ha cap criteri objectiu que permeti identificar des de fora un acte propi de violència divina, «el mateix acte que, per un observador extern, és només un esclat de violència, pot ser diví per als qui hi estan implicats» (Žižek, 2009: 172). En aquest punt, la distinció benjaminiana sembla que s'esfondra, la voluntat no bastarda del seu text veu perillar la puresa de l'aspecte diví que voldria salvar i, nogensmenys, el nom mateix amb què Benjamin va batejar la violència legítima apunta a una barreja entre el fet polític i el religiós, que és en el fons mateix d'aquest debat sobre la violència i la seva presumpta irracionalitat. Aventurem-nos una mica més en aquest problemàtic assumpte sense desestimar allò que fins aquí s'ha guanyat, el vincle originari $\mathrm{i}$ ja indiscutible entre política $\mathrm{i}$ violència $\mathrm{o}$, en terminologia de Benjamin, entre violència conservadora i violència mítica o fundacional. 


\section{La crítica al gir teologicopolític}

Quan avui es parla d'un «retorn del fet religiós», s'al-ludeix, amb aquesta expressió, a fenòmens diversos: d'una banda, els anomenats "fonamentalismes», que promourien tant accions terroristes com determinats comportaments atàvics en el si de les nostres societats laiques i civilitzades; d'altra banda, la presència cada cop més sospitosa de manifestacions de caràcter religiós en l'espai públic, així com la preocupant connivència entre religió i estat, que hauria desembocat en una mena de "reteologització de l'Estat» (López Petit, 2003: 37), el qual es permetria justificar les seves accions, i en especial les seves intervencions armades, a partir d'arguments teologicopolítics — tal com va fer l'Administració Bush després de l'atemptat de les Torres Bessones, per exemple- i, finalment, aquest «retorn» faria també esment a una onada de plantejaments teòrics i filosòfics postmarxistes que reclamarien pensar el fet religiós i que «estarien proporcionant una renovada munició dialèctica, argumentativa, a posicions practicoteòriques sobradament conegudes» (Cruz, 2007: 150).

No seria gaire arriscat aventurar que tots aquests fenòmens són, en realitat, l'expressió d'una mateixa problemàtica, aquella dificultat irresolta que hem heretat de la modernitat, la relació sempre indòcil entre creença i saber. Les crítiques cap als fonamentalismes i determinats comportaments forans solen realitzar-se des de l'ideal d'estats racionals i laics que "creuen saber», en terminologia de Derrida, és a dir, que creuen que s'han alliberat una vegada per totes d'allò mític. Tanmateix, tal com hem anat mostrant, si l'estat, la llei i el dret no són aliens a la violència, cal pensar que tampoc no ho són al fet mític i/o religiós. De fet, seguint aquí Nancy (2006: 102), si bé la polis ha nascut com a reivindicació de l'autonomia civil davant l'heteronomia de les teocràcies, si bé l'autonomia ha estat el principi del que és polític en declarada resistència a l'autoritarisme d'arrel religiosa, aquesta separació ha estat sempre inestable, i això no s'ha produït només a causa d'una lluita històrica entre forces contraposades. Els motius de la precarietat d'aquesta separació, d'aquesta indistinció originària entre creença i saber en termes polítics, són dos. D'una banda, el fet que, en el fonament de l'estat, de la llei i de l'ordenació jurídica, rau el que és mític, cosa que sabem ja des de la definició de sobirania de Schmitt — per més que rebutgem les conseqüències que extrau d'aquesta tesi, és a dir, la indistinció entre democràcia i estat totalitari-, i que Benjamin i Derrida, per no esmentar aquí Agamben, s'encarregaran de recordar. La sobirania política de l'estat, el concepte mateix de sobirania, conté sempre una dimensió teologicopolítica. L'acte excepcional pel qual s'institueix la llei, el moment de decisió que permet "fer la llei», prové sempre d'una força performativa, d'una violència que exigeix, i seguirà exigint a partir de la seva instauració, un acte de fe. En paraules de Derrida: «El sorgiment mateix de la justícia i el dret, el moment instituent, fundador i justificador del dret implica una força realitzativa, és a dir, implica sempre una força interpretativa i una crida a la creença» (Derrida, 1994: 32). Així mateix, pel que fa al compliment de la llei, aquest no prové pas de la seva racionalitat i justícia, sinó, tal com ja mostrava Montaigne, de la seva 
autoritat, és a dir, d'allò que Derrida recollirà com el «fonament místic de l'autoritat» (Derrida, 1994: 29). Això no vol pas dir que les lleis no hagin de ser tan justes com sigui possible, sinó només que la llei, l'estat, la política, han necessitat sempre la força i la creença, tant en la fundació com en l'acompliment. Si Benjamin podia anomenar «mítica» la violència fundadora era també, doncs, per aquest component de creença que l'empeny des de la seva instauració. D'altra banda, el segon motiu que fa indiscernible racionalitat i creença des d'una perspectiva política és la pervivència d'elements mítics, heterònoms, dins de les societats occidentals, encara que aquestes vulguin ser laiques. Que també les democràcies requeririen aquest component afectiu i, per tant, heterònom, ho sabia ja de vell antuvi algú com Rousseau, quan reclamava una «religió civil», però encara avui Nancy ens recorda com la idea mateixa de «fraternitat» tracta de condensar tota l'afectivitat que una política democràtica es podria permetre: «Si bé l'autonomia resisteix l'heteronomia mitjançant totes les representacions de la democràcia, l'heteronomia resisteix l'autonomia en la força de l'afecte» (Nancy, 2006: 109), i la fraternitat representaria aquest paper afectiu que faria possible la democràcia més enllà de les seves lleis reguladores però també coactives. I, molt abans que Nancy —i aquí encetem ja un altre dels fenòmens que semblaven justificar la idea d'un retorn del fet religiós-, Georges Bataille havia reparat en l'existència d'aquells «elements heterogenis» d'una societat que es caracteritzen pel seu rebuig al rendiment, la productivitat, la finalitat, aquells elements que, en la festa, en l'erotisme, en les manifestacions d'allò «sagrat» justament, materialitzarien la despesa improductiva: «la violència, la desmesura, el deliri, la bogeria caracteritzen els elements heterogenis en diferents graus» (Bataille, 1993: 17), i precisament el feixisme s'hauria mostrat capaç de mobilitzar aquests elements com no ho havia sabut fer el moviment obrer. Així doncs, malgrat totes les precaucions i restriccions que sembla que posa en funcionament el projecte il.lustrat en la seva vessant política envers els elements heterogenis, heterònoms, afectius, mítics i religiosos, sembla que l'anàlisi d'Adorno i Horkheimer a Dialèctica de la Il-lustració no deixa de confirmar-se una vegada i una altra, no que l'aspecte mític perviu en la racionalitat il.lustrada com a residu del passat, sinó que la mateixa Il-lustració produeix l'aspecte mític com la seva ombra. D'això n'han retut compte totes aquelles filosofies franceses de la sacralitat, de Bataille a Roger Caillois, Leiris i Klossowski, i, en general, tot el moviment vinculat al Col.legi de Sociologia, que, tot i fer arrufar el nas a Adorno (Benjamin i Adorno, 1999: 212), treballava en la mateixa línia per fer visibles els elements mítics que no només donarien lloc al feixisme, sinó que també perviurien inconscients a les societats aparentment seculars. La indiscernibilitat entre racionalitat $\mathrm{i}$ creença, política i violència, autonomia i heteronomia pertany, doncs, de ple als nostres ordenaments jurídics i socials, tant des del seu origen com en la seva subsistència. Si les filosofies de la diferència, de la sacralitat o, simplement, alguns plantejaments postmetafísics han tractat aquesta indiscernibilitat no és, de ben segur, per donar arguments a posicions antidemocràtiques o autoritàries, sinó per fer-nos conscients del lloc des del qual parlem i sovint jutgem 
allò altre, el lloc, tanmateix, des d'on hauria de ser possible pensar en altres termes la nostra relació amb la creença, amb la violència i amb el fet polític.

És ben cert que aquest tipus d'anàlisi pot donar lloc a una reteologització de la política gens desitjable. Alguns plantejaments anglosaxons sembla que han copsat aquesta possibilitat i han tractat de cercar, a partir d'una certa lectura de Kierkegaard, de Schmitt i de les anàlisis desconstructives, la base teòrica per a la constitució d'una sociabilitat, una comunitat, afermada per la creença: «la qüestió política [...] és com aquesta fe dels sense fe seria capaç de lligar junts la confraternitat, la germanor o, per utilitzar el terme de Rousseau, una associació» (Critchley, 2012: 4) ${ }^{6}$. La crítica a la pretesa separació entre política i religió pot, sens dubte, fer retornar velles posicions teòriques o bé remitologitzar nocions de les quals semblava que sortosament ja ens havíem desempallegat, i això és especialment arriscat pel que fa a la idea de comunitat, per més que aquesta es presenti com a comunitat de «no creients», tal com fa Critchley, o com a "comunitat dels sense comunitat", tal com ja havia plantejat Bataille, inaugurant, amb aquesta noció, totes les filosofies postmetafísiques de la comunitat (Bataille, 1976; Blanchot, 1983; Nancy, 1986; Esposito, 2003). Semblaria, però, que els plantejaments de Žižek i Derrida eludeixen aquesta deriva, i en aquest sentit ens són valuosos. A Fe i saber, Derrida planteja no només que raó i creença tenen la mateixa font, és a dir, que l'anomenat «retorn de la religiositat» no s'entendria desvinculat del desenvolupament cientificotècnic que suposa també la religió, sinó que, a més, consegüentment amb aquesta tesi, també la democràcia depèn d'una certa experiència fiduciària. La fe entesa com a creença en l'altre més enllà de tot saber, en oposició a allò que sabem o que creiem saber, és essencial per l'existència mateixa de qualsevol vincle social, cosa que exemplifica bé el testimoni, la paraula que, en ser pronunciada, apel.la al crèdit i a la creença, pressuposa que algú estigui disposat a creure en aquesta paraula com si fos vertadera. Fins i tot quan es menteix, i sobretot si es menteix, l'atestació exigeix un acte de fe per part d'aquell qui rep $i$ acull les paraules dites, $i$ una demanda de fe per part de qui les pronuncia, de manera que aquesta estructura fiduciària de l'atestació es mostra inherent a qualsevol fenomen filosòfic, científic, històric o religiós (Derrida, 1996: 97). Ara bé, si, d'una banda, la creença es, en realitat, una experiència quotidiana $\mathrm{i}$ respecte al vincle social no deixa de ser aquell element heterònom que, com deia Nancy, conforma l'afectivitat del que és polític, cal accentuar la diferència entre creença i saber per copsar un concepte exigent de fe - tal com, per exemple, reconeix Derrida en la versió kierkegaardiana d'Abraham- ${ }^{7}$, que s'articula en clara oposició a allò que se sap o que es creu saber. El que Derrida anomena "fe en la possibilitat de l'impossible», o bé «messianicitat sense messianisme», consisteix precisament en la creença en allò que no se sap ni es pot preveure. Creure en aquell a qui ja coneixem d'antuvi, creure perquè sabem

6. També Hent de Vries semblava que advocava per aquesta línia a De Vries (2002).

7. Sobre les connexions de Derrida amb Kierkegaard, vegeu Mjaaland (2008) i Llevadot (2013). 
qui és l'altre i com es comportarà, creure en el futur perquè hem construït un present que s'hi encamina, no és pas creure, sinó calcular, desplegar un programa, considerar les possibilitats per tal de minimitzar l'esdeveniment. Però si la democràcia representa alguna cosa és, justament, apertura a l'altre, creença en l'esdeveniment, l'afirmació d'allò que està per venir, en sigui quina en sigui la identitat, si és que existeix. Aquesta apertura a l'alteritat és el que Derrida anomenava, ja a Espectres de Marx, «messianicitat», i en feia dependre la possibilitat de la democràcia (Derrida, 1993: 102). Si ara situem aquesta proposta en el context de la reflexió present, es fa palès que la no-desvinculació radical entre política i religió no té com a conseqüència cap retorn a l'autoritarisme teocràtic, ans al contrari, l'element fiduciari esdevé la clau per obrir la democràcia més enllà del seu límit jurídic, per tant, més enllà de la seva violència conservadora. La creença en «l'arribant» — tal com Derrida a voltes l'anomena (Derrida, 2003: 127) — no només obre el dret a la justícia i evita així la pitjor de les violències, sinó que també eludeix tota temptació comunitària i comunitarista, car el vincle social no pot passar mai per allò que tenim en "comú» amb l'altre, i en virtut del qual en fem comunitat, sinó precisament per la seva heterogeneïtat, que és la que reclama el crèdit com a fonament de tota relació. És en aquest sentit que la messianicitat derridiana, en la mesura en què implica la creença en la justícia més enllà del dret i l'apertura a allò altre que em depassa, em qüestiona i destorba la meva individualitat, suposa un cert tipus de «violència divina» benjaminiana. Una violència que, sense ser fundadora, sí que sol.licita i fa tremolar les certeses sobre les quals s'alçava la identitat d'un estat de dret o la identitat amb si mateixa d'una societat que tendeix sempre a conservar-se de manera també violenta.

I és en aquest sentit que sembla treballar també Žižek, tot i que ho fa amb una estratègia ben diferent, quan planteja que «Davant l'antiga calúmnia liberal que estableix un paral-lelisme entre la concepció messiànica de la història en el cristianisme i en el marxisme, com en el procés que condueix a la salvació final dels fidels (el ben conegut motiu d'"els partits comunistes són sectes religioses secularitzades"), ¿no caldria recalcar que això només és vàlid pel marxisme "dogmàtic" ossificat, i no pas pel seu veritable nucli emancipador? D'acord amb Alain Badiou, en el seu llibre renovador sobre sant Pau, la nostra premissa és aquí exactament la contrària: en lloc d'adoptar aquesta postura defensiva, que permet a l'enemic definir el terreny de la lluita, el que cal fer és invertir l'estratègia i acceptar plenament allò de què séns acusa: sí, el cristianisme i el marxisme pertanyen al mateix llinatge, [...] l'autèntic llegat cristià és massa preciós per deixar-lo en mans de fonamentalistes pertorbats» (Žižek, 2000: 2). El que fa Žižek, doncs, és acceptar la indiscernibilitat entre política i religió, i, en lloc de proclamar la laïcitat i la racionalitat de les polítiques antiautoritàries com la darrera "petita esperança que els queda als sense esperança», tal com assenyalava Bronner, insta a recuperar el llegat cristià per extreure'n un enfocament polític força radical. En aquest sentit, l'experiència fiduciària que Žižek invoca no és ja la fe derridiana en la «possibilitat de l'impossible», sinó la «fe en la realitat de l'impossible» (Žižek, 1999: 238-239), ja que, segons la tradició 
cristiana i a diferència de la jueva, a la qual sembla que respongui el plantejament de Derrida, l'impossible ha esdevingut, l'encarnació és l'esdeveniment exemplar d'aquesta impossibilitat realitzada, com també ho és per Žižek l'amor o la revolució (Žižek, 2001: 84), i del que es tracta, d'aleshores ençà, és d'estar a l'altura d'aquest esdeveniment fonamental. Per Žižek, allò que és actualitzable del llegat cristià, allò que, d'alguna manera, seguiria vigent per tal d'adoptar una visió crítica davant la violència conservadora i que permetria democratitzar les democràcies és, d'una banda, el concepte de comunitat paulina, que, juntament amb Badiou, entendrà com un «universalisme incondicional» $i$, d'altra banda, la figura de Crist entesa com a «subversió de la llei» davant del «doble obscè» a què apuntaria el judaisme. Pel que fa a la primera qüestió, Žižek entén el «ja no hi ha jueu ni grec, ni serf ni lliure, ni home ni dona» de Gàlates (Gàlates III, 26-28) en termes d'una comunitat de la «resta», un romanent que s'oposaria a qualsevol comunitarisme identitari, perquè només hi pertanyerien aquells que no pertanyen a cap comunitat, una mica com els «sense part» dels quals parla Rancière, i que, en la terminologia lacaniana que a Žižek li plau de fer ús, suposaria la renúncia a la xarxa simbòlica, a la substància ètnica i/o a la comunitat orgànica de la qual creiem que formem part, d'aquí l'exigència d'odiar el pare, la mare, «els nostres»..., de què es parla a Lluc XVI, 26. D'altra banda, el que també encarna per a Žižek la figura de Crist és la subversió de la llei. Žižek interpreta el «Crist ens va redimir de la maledicció de la llei» (Gàlates III, 13) com una renúncia al suplement utòpic. Allà on el judaisme oposa a la violència de la llei una alteritat, el seu «doble obscè», la fantasia del messianisme, el cristianisme, mitjançant la crucifixió, es desfa d'aquest horitzó utòpic. La crucifixió, la lesió irreparable que Déu s’infligeix a si mateix, fa desaparèixer, una vegada per totes, la creença en l'alteritat fantasmagòrica que, malgrat tot, fa la vida, i la violència que la preserva, suportable. El cristianisme hauria aportat, per Žižek, la desaparició de l'horitzó de possibilitat i es presentaria aleshores com una alternativa al plantejament derridià del qual Žižek dirà que es manté sempre en una «impossibilitat estructural» (Žižek, 2001: 83) que impedeix l'acció.

Però, més enllà de l'oposició entre Žižek i Derrida pel que respecta a la seva concepció de la impossibilitat vinculada a la creença, cristiana per un, jueva o estructural per l'altre, més enllà de l'estil pausat, elegant, voluntàriament contingut de l'un i de la precipitació, l'efervescència i el ritme trepidant de l'altre, més enllà fins i tot de l'aparent discussió entre tradicions religioses, els termes de la qual el propi Derrida no acceptaria — car el seu concepte de messianicitat defuig tot concepte jueu de messianisme-, el fet és que aquests dos pensaments ens obren la possibilitat d'entendre certs fenòmens massa facilment titllats d'irracionals i d'entendre'ns a nosaltres mateixos d'una manera altra en la mesura en què ens permeten copsar la complexitat que ens travessa. Això no vol pas dir que no calgui insistir en la crítica als fonamentalismes religiosos i als arguments obscurantistes, sinó més aviat que aquesta crítica necessària no pot seguir fent-se en nom d'una raó pura, civilitzada i desvinculada de tota mitologia, en nom d'una mundialatinització, que no deixa de ser una religió 
que oculta el seu nom, en nom d'un etnocentrisme amb rostre universalista (Derrida, 1996: 66), d'un universalisme democràtic que amaga la seva arrel religiosa alhora que l'empeny un impuls ben ecumènic. La crítica potser hauria de començar a voler entendre que és contra aquest universalisme democràtic, pretesament laic i carregat de raó que semblen revenjar-se, sovint des de la humiliació i la fam, certs comportaments atàvics, sacrificials i suïcides convocant una violència divina que, sens dubte, ha de ser qüestionada, però aquest qüestionament hauria d'apuntar als projectes identitaris i comunitaristes, a la pretensió de puresa i d'indemnitat que els enarboren, a la finalitat fundadora a què apunten, i no pas tant cap allò que tenen d'irracional. La raó que sigui pura, que tiri la primera pedra i, en tirar-la, que ho faci sense violència, si és que es pot. D'altra banda, aquesta raó impura, amarada de silencis i violències, l'única de què disposem si es que en podem disposar, potser tindrà l'oportunitat de repensar-se a partir del seu llegat contaminat i mestís, tal com Benjamin, Derrida o Žižek han mostrat que és possible i necessari fer.

\section{Referències bibliogràfiques}

Abensour, M. (1997). La démocratie contre l'État. París: PUF.

- (2012). «Democracia insurgente e institución». Enrahonar, 48, 31-48.

Agamben, G. (2006). Homo sacer: El poder soberano y la nuda vida. Valencia: Pre-Textos.

Arendt, H. (1970). On Violence. Nova York: Harcourt, Brace \& World. Versió espanyola: Sobre la violencia. Madrid: Alianza, 2005. Traducció de Guillermo Solana.

Balibar, E. (1994). «Violence et politique: Quelques questions». A: Mallet, M.-L. (ed.). Le passage des frontières (autour de l'ouvre de Jacques Derrida). París: Galilée.

Bataille, G. (1976). Sur Nietzsche: Volonté de Chance. París: Gallimard. Versió espanyola: Sobre Nietzsche: Voluntad de suerte. Madrid: Taurus, 1972. Traducció de Fernando Savater.

- (1993). El Estado y el problema del fascismo. Valencia: Pre-Textos.

Benjamin, W. (2007). «Hacia la crítica de la violencia». A: Obras. Llibre II, vol. 1. Madrid: Abada. Traducció de Jorge Navarro Pérez.

Benjamin, W. i Adorno, T. W. (1999). «Letter Adorno to Benjamin, 22.9.1937». The complete correspondence 1928-1940. Nova York: Polity Press.

Biset, E. (2013). «La violencia y sus formas». A: Penchaszadeh, A. i Biset, E. (eds.). Derrida politico. Buenos Aires: Colihue.

Blanchot, M. (1983). La communauté inavouable. París: Minuit.

Bronner, S. (2005). "Of Reason and Faith: A Reply to His Holiness Pope Benedict XVI». Logos, 4 (1), primavera.

Butler, J. (2006). «Critique, Coertion, and Sacred Life in Benjamin's Critique of Violence». A: De vries, H. i Sullivan, L. E. (eds.). Political Theories: Public Religions in a Post-secular World. Nova York: Fordham University Press. 
Critchley, S. (2012). The Faith of the faithless: Experiments in Political Theo$\log y$. Londres i Nova York: Verso.

Cruz, M. (2007). «Emancipación: la pérdida de hegemonía de un concepto (del trascendentalismo al fanatismo, pasando por la banalidad)». A: CRUZ, M. (ed.). Odio, violencia, emancipación. Barcelona: Gedisa.

Derrida, J. (1992). «Donner la mort». A: Rabaté, J. M. i Wetzel, M. (eds.). L'Éthique du don: Jacques Derrida et la pensée du don. París: MétailiéTransition. Versió espanyola: Dar la muerte. Barcelona: Paidós, 2000. Traducció de Cristina de Peretti i Paco Vidarte.

- (1993). Spectres de Marx: L'État de la dette, le travail et le denil et la nouvelle Intrenationale. París: Galilée.

- (1994). Force de loi. París: Galilée.

- (1996). Foi et savoir. París: Éditions du Seuil.

- (2003). Voyous: Deux essais sur la raison. París: Galilée.

De Vries, H. (2002). Religion and Violence: Philosophical Perspectives from Kant to Derrida. Baltimore / Londres: Johns Hopkins University Press.

Engels, F. (2003). La revolución de la ciencia de Eugenio Dühring ("AntiDühring»). Moscú: Instituto del Marxismo-Leninismo / Editorial Progreso.

Esposito, R. (2002). Immunitas: Protección y negación de la vida. Buenos Aires: Amorrortu.

- (2003). Comunitas. Buenos Aires: Amorrortu.

Llevadot, L. (2013). Kierkegaard through Derrida: Toward a Postmetaphysical Ethics. Colorado: Davies Group Publishers.

López Petit, S. (2003). El Estado-guerra. Hondarribia: Hiru.

Mjanland, M. T. (2008). Autopsia. Self, Death and God after Kierkegaard and Derrida. Berlín / Nova York: Walter de Gryter.

Nancy, J.-L. (1986). La communauté désoeuvrée. París: Ch. Bourgois.

- (2006). "Church, State, Resistance». A: De Vries, H. i Sullivan, L. E. (eds.). Political Theories: Public Religions in a Post-secular World. Nova York: Fordham University Press.

Pardo, J. L. (1998). «Políticas de la intimidad». Logos: Anales del Seminario de Metafisica, 1, 145-196.

Rancière, J. (1998). Aux bords du politique. Paris: La Fabrique.

ŽıžEK, S. (1999). The Ticklish Subject: The absent centre of political ontology. Londres: Verso.

- (2000). The fragile Absolute - or Why is the Christian legacy worth fighting for? Londres / Nova York: Verso.

- (2001). On Belief. Londres / Nova York: Routledge.

- (2002). Did somebody say totalitarism? Nova York: Verso.

- (2009). Violence: Six Sideway Reflexions. Londres: Profile Books Ltd. 
Laura Llevadot. Professora de Filosofia Contemporània a la Universitat de Barcelona. Ha estat investigadora al Søren Kierkegaard Research Centre de la Universitat de Copenhage, a la Howard and Edna Hong Kierkegaard Library (Minneapolis, USA), i a la Universitat de Paris 8. Actualment és membre de la Cátedra de Filosofía Contemporánea i investigadora associada del Laboratoire d'études et de recherches sur les Logiques Contemporaines de la Philosophie (Université Paris VIII). Entre les seves publicacions destaquen La philosophie seconde de Kierkegaard (L'Harmattan, 2012); Kierkegaard through Derrida (The Davies Group, 2013) i la coordinació amb Jordi Riba de Filosofias postmetafisicas. 20 años de filosofía francesa contemporánea (UOC, 2012).

Laura Llevadot Professor of Contemporary Philosophy at the University of Barcelona. Researcher at the Søren Kierkegaard Research Centre at the University of Copenhagen, at the Howard and Edna Hong Kierkegaard Library (Minneapolis, USA), an at the Université Paris 8. Member of the Cátedra de Filosofia Contemporánea and associate researcher at the Laboratoire d'études et de recherches sur les Logiques Contemporaines de la Philosophie (Université Paris VIII). She has published La philosophie seconde de Kierkegaard (L'Harmattan, 2012); Kierkegaard through Derrida (The Davies Group, 2013) and co-edited with Jordi Riba Filosofias postmetafísicas. 20 años de filosofia francesa contemporánea (UOC, 2012). 